\title{
DRUG THERAPY FOR SPASTICITY AS A CAUSE FOR DETERIORATING FUNCTION IN SPINAL PARALYSIS
}

\author{
By Alvin A. Freehafer, M.D., ${ }^{1}$ Coletta Hazel, R.N., ${ }^{1}$ and Rosemary \\ LINDAN, M.D. ${ }^{2}$ \\ ${ }^{1}$ Department of Orthopaedics, Case Western Reserve University School of Medicine, \\ University Hospitals. ${ }^{2}$ Cleveland Metropolitan General Hospital, Cleveland, Ohio, \\ U.S.A.
}

\begin{abstract}
Spasticity has been defined physiologically as 'a motor disorder characterised by a velocity dependent increase in tonic stretch reflexes ('muscle tone') with exaggerated tendon jerks, resulting from hyperexcitability of the stretch reflex, as one component of the upper motor neuron syndrome' (Lance, I980). Other components of disorders of the upper motor neuron include spasms, weakness, and loss of dexterity. Troublesome spasticity in patients with spinal cord injury is common. Several drugs have been used to overcome the symptoms of the upper motor neuron syndrome. One of the most effective has been diazepam which enhances pre-synaptic inhibition in the spinal cord by facilitating the postsynaptic effects of gamma-aminobutyric acid (Costa and Guidotti, 1979). Diazepam is effective at numerous levels of the neuraxis, producing tranquillising, sedative, and anti-convulsant effects in addition to relaxation of skeletal muscle (Young and Delwaide, I98I).

Three patients with incomplete paralysis from spinal cord injury were treated for spasticity. Drug therapy was effective but muscle strengths diminished so that the patients stopped walking. Changes in medication resulted in return of strength and function. Two patients had their paralysis because of gunshot wounds and were thought by some to have infection. Surgical intervention was recommended to 'decompress' what was thought to be abscesses. Fortunately, drug therapy for their spasticity was discontinued and all of the patients improved.

It is important to realise that drugs that are effective in controlling spasticity may cause muscle weakness.
\end{abstract}

\section{REFERENCES}

Costa, E. \& Guidotri, A. (1979). Molecular Mechanisms in the Receptor Action of Benzodiazepines. Annu. Rev. Pharmacol. Toxicol., 19, 53 I-545.

LANCE, J. W. (I980). Symposium Synopsis. In Feldman, R. G., Young, R. R., Koella, W. P. Ed. Spasticity: Disordered Motor Control. Year Book, Chicago.

Young, R. R. \& Delwaide, R. J. (I98I). Drug Therapy. N. Eng. F. Med., 304, 28-33 and $96-99$.

This Proferred paper was read at the Meeting of the International Medical Society of Paraplegia, Stoke Mandeville Hospital, Aylesbury, Bucks., in July I98I. 